\section{Grapevine and Soil Water Relations with Nodding Needlegrass (Nassella cernua), a California Native Grass, as a Cover Crop}

\author{
Michael J. Costello ${ }^{1}$ \\ Cooperative Extension, University of California, Fresno, CA
}

\begin{abstract}
Additional index words. soil moisture, vineyard, grape, floor management
\end{abstract}
\begin{abstract}
Nodding needlegrass [Nassella cernua (Stebbins \& R.M. Love) Barkworth], a California native perennial grass, was tested for its effects on grapevine and soil-water relations in a drip-irrigated vineyard in Parlier, CA. Vine water status and in-row and between-row soil moisture (at $0.3 \mathrm{~m}, 0.6 \mathrm{~m}, 0.9 \mathrm{~m}, 1.2 \mathrm{~m}$, and $1.5 \mathrm{~m}$ ) were monitored semiweekly from June to September. There was no overall significant difference in leaf water potential between treatments. In-row soil moisture was lowest at depths of $0.6 \mathrm{~m}$ to $0.9 \mathrm{~m}$ within the nodding needlegrass treatment but was lowest from $0.3 \mathrm{~m}$ to $0.9 \mathrm{~m}$ within the clean cultivation treatment. Compared with clean cultivation, nodding needlegrass in-row soil moisture was significantly higher at depths of $0.3 \mathrm{~m}$ and 0.6 . $\mathrm{m}$ and did not differ at depths of $0.9 \mathrm{~m}$ and $1.2 \mathrm{~m}$. In contrast, in-row soil moisture was significantly higher under clean cultivation compared with nodding needlegrass at $1.5 \mathrm{~m}$. Betweenrow soil moisture was significantly higher under clean cultivation compared with nodding needlegrass at every depth. Combining in-row and between-row data, overall vineyard soil moisture was slightly lower, by $1.2 \%$ points, in the nodding needlegrass treatment compared with clean cultivation. There was no interaction between treatment and depth for between-row soil moisture, indicating that the vines used little water from the between-row area. The lack of difference between treatments in the rate of soil moisture depletion over the season indicates that nodding needlegrass used little water during the summer. Based on these results, nodding needlegrass appears to be suitable as a permanent cover crop in California drip-irrigated vineyards where competition for summer water is a concern.
\end{abstract}

Cover cropping in California vineyards is recognized as having multiple management challenges, chief among them water use (Ingels et al., 1998). California has a Mediterranean climate with clearly defined rainy and dry seasons. Average annual rainfall in the San Joaquin Valley city of Fresno is $\approx 300$ $\mathrm{mm}$ with $82 \%$ falling in the off-season (1 Nov. to 31 Mar.), and the vast majority of vineyards in the San Joaquin Valley are irrigated. The use of drip irrigation has become increasingly common, and under this

Received for publication 2 Dec. 2009. Accepted for publication 22 Jan. 2010.

I thank the University of California Sustainable Agriculture Research and Education Program, which provided funding for this study.

Thanks also to laboratory assistants Jose Cantu, Abebe Gebreheiwet, Kimberly Miyasaki, Juliet Schwartz, and Jonathan Wroble for their data collection efforts; to Ron Brase of California $\mathrm{Ag}$ Quest for assistance with the neutron probe readings; and to Scott Stewart of Conservaseed (Rio Vista, CA) for project inspiration and for providing the native grass seed. I am also grateful for the assistance of UC Cooperative Extension advisors Chuck Ingels, Tim Prather, Kurt Hembree, and Dan Munk.

${ }^{1}$ Current address: Horticulture and Crop Science Department, Cal Poly State University, 1 Grand Avenue, San Luis Obispo, CA 93407.

e-mail mcostell@calpoly.edu. system, between-row floor vegetation is typically managed during the growing season through cultivation or mowing (McGourty and Christensen, 1998). The negative consequences of frequent cultivation are that it disturbs floor vegetation root channels and accelerates the rate of organic matter decomposition, which collectively can lead to poor water penetration (Gulick et al., 1994). Maintaining and managing floor vegetation through mowing is much less disruptive to the soil and therefore can promote soil colloid aggregation, increase soil pore size, reduce compaction, and improve water infiltration (Celette et al., 2005; Goulet et al., 2004; Klik et al., 1998; McGourty and Christensen, 1998). However, there is concern about the amount of water used by the floor vegetation and how it might affect vine growth and/or yield.

In regions with a Mediterranean climate, annual cover crops are typically winter annuals, which are planted in fall and senesce by late spring. Because their growth is primarily in the off-season, and their water source is primarily rainfall, direct competition with the grapevines for water is minimized. However, after senescence in spring, weeds will take the place of the cover crop and must be managed to prevent excessive competition. An alternative is the maintenance of a perennial cover crop, which provides similar benefits as an annual cover crop while avoiding the drawbacks of invasive weeds. However, all of the nonnative perennials that have been tested as cover crops in California vineyards or orchards either require summer water or are competitive enough with the vines to decrease vigor or yield (Gulick et al., 1994; Ingels et al., 2005; Prichard et al., 1989; Wolpert et al., 1993). Two studies have evaluated California native grasses in vineyards (Baumgartner et al., 2008; Ingels et al., 2005), and neither found a negative effect on grape yield.

Several studies have looked at how vineyard cover crops affect soil- and plant-water relations. Celette et al. (2005), working in a nonirrigated vineyard in Languedoc-Roussillon, France, found that soil water content with a tall fescue (Festuca arundinacea Shreb.) cover crop was higher at a depth of $0.75 \mathrm{~m}$ from spring to midsummer, but at other depths, soil water was equivalent to clean cultivation. Gulick et al. (1994) looked at continuous floor vegetation (Bromus hordeaceus L. subsp. hordeaceus in the winter followed by mowed weedy vegetation in the summer) in a San Joaquin Valley, furrowirrigated vineyard. They found that the cover increased soil water infiltration by more than twofold, but also increased between-row soil water depletion compared with cultivation. King and Berry (2005), working in a dripirrigated vineyard, found higher betweenrow soil moisture with a Trifolium fragiferum L. cover crop versus a blend of California native grasses: Elymus glaucus Buckley, Hordeum brachyantherum Nevski, and Bromus carinatus Hook. \& Arn. However, this study limited soil moisture measurements to the top $10 \mathrm{~cm}$ of soil and did not compare the cover crops to clean cultivation.

The intent of the present study was to evaluate the potential for California native grasses as vineyard cover crops, and furthermore, how one species, nodding needlegrass, affects soil- and vine-water relations. Vine vigor and yield data of nodding needlegrass and other cover crops in this study are presented in another paper (Costello, 2010). The native range of nodding needlegrass extends from the Sacramento and San Joaquin Valleys through the coastal regions of central and southern California (Beetle, 1947). Little biological information is available for this species, and most of what exists pertains to characteristics such as seed, leaf, and inflorescence morphology, and ecological adaptations such as drought tolerance or geographical distribution (Amme, 2003; Barkworth and Torres, 2001). Observations suggest that it has a high degree of summer dormancy, remaining dormant midsummer even in the presence of available soil moisture. If this is the case, then it should provide the advantages of a perennial cover crop without the disadvantage of excessive competition with the vines for water. Clary (2006) found that nodding needlegrass exhibited a low summer cuticular transpiration rate, suggesting a drought tolerance mechanism. This study evaluated summer soil moisture and vine leaf water potential patterns with 


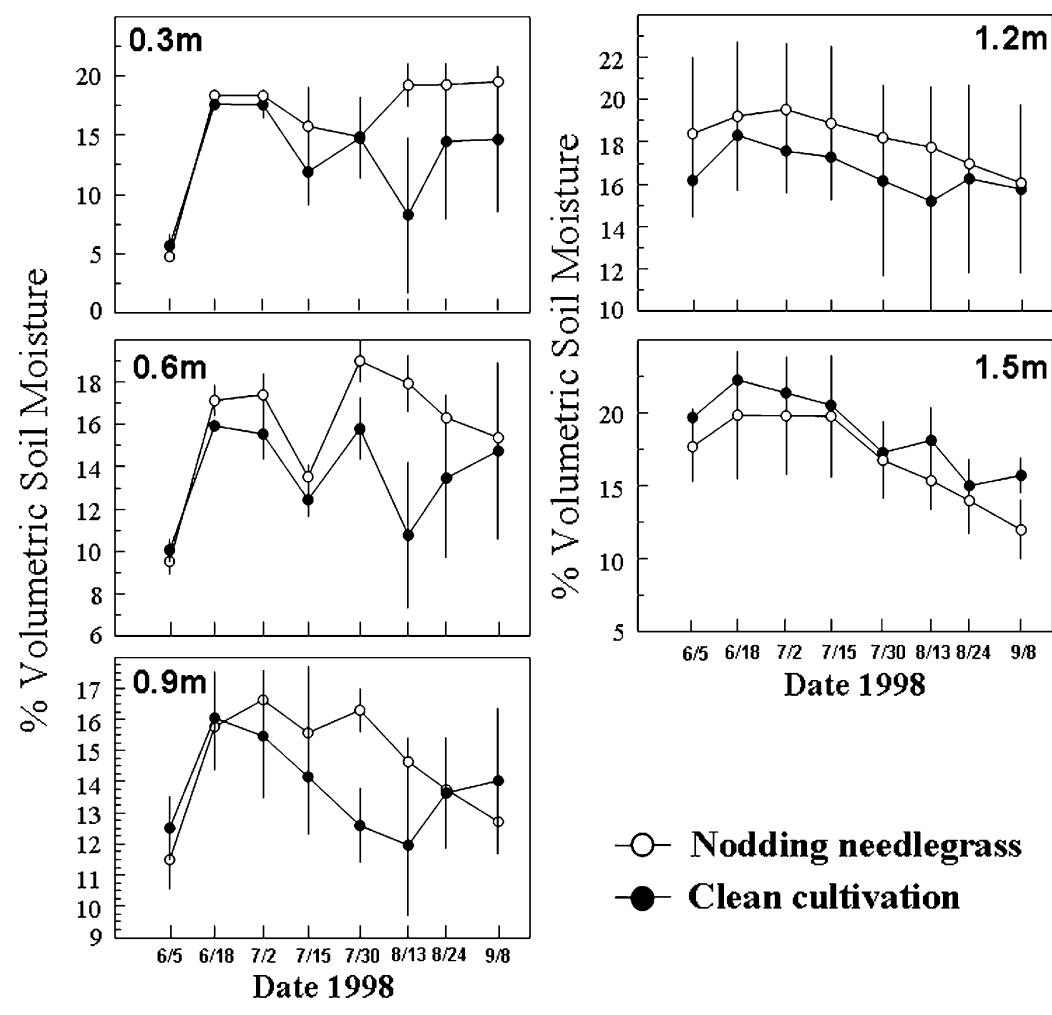

Fig. 1. Mean in-row soil moisture, 1998 season. Percent volumetric soil moisture content \pm SE estimated from neutron probe readings taken weekly from June to September, nodding needlegrass versus clean cultivation treatments.
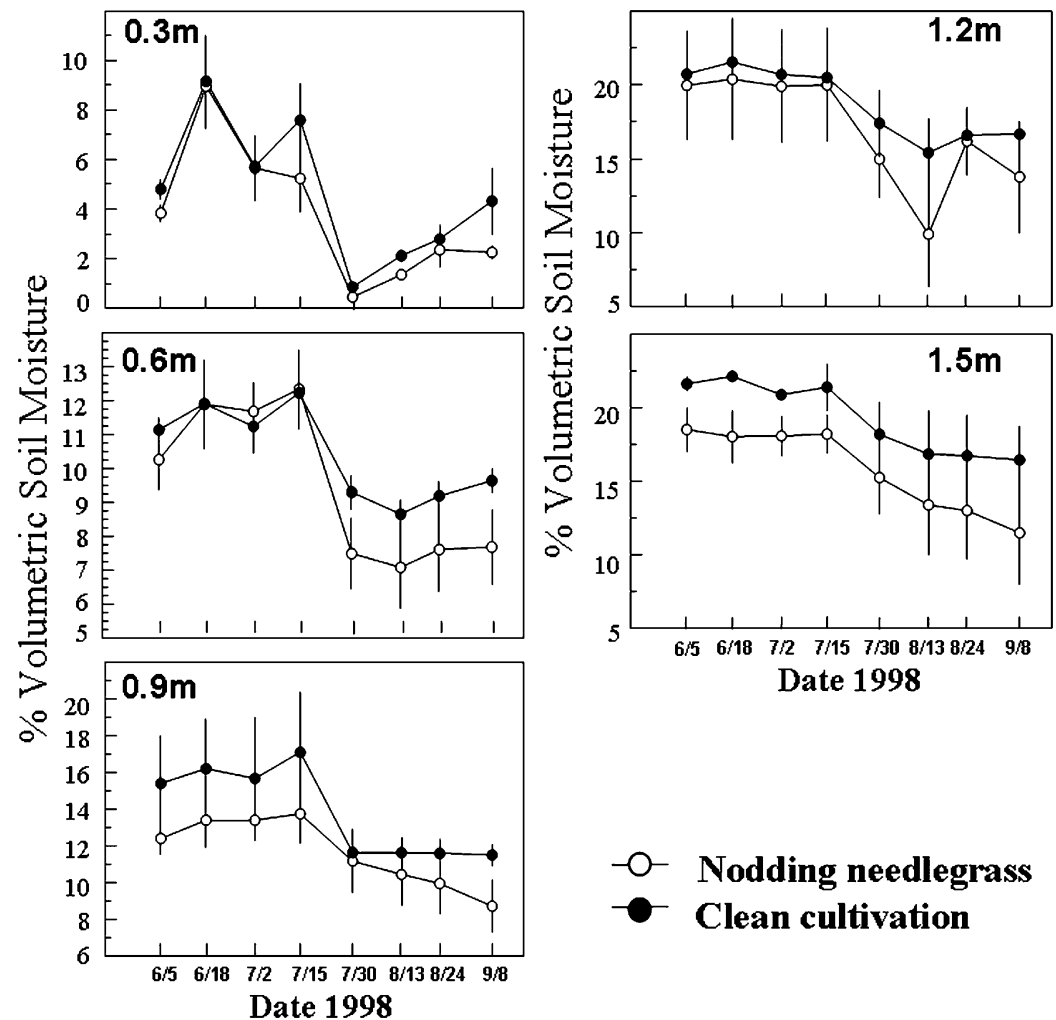

\section{- - Nodding needlegrass Clean cultivation}

Fig. 2. Mean in-row soil moisture 1999 season. Percent volumetric soil moisture content \pm SE estimated from neutron probe readings taken weekly from June to September, nodding needlegrass versus clean cultivation treatments. nodding needlegrass as a cover crop compared with clean cultivation.

\section{Materials and Methods}

The experimental site was at the University of California Kearney Agricultural Center in Parlier, in the San Joaquin Valley, in a warm climatic region, classified as a Viticultural Region V (Winkler et al., 1974). Mean high and low temperatures in August are 35 and $16^{\circ} \mathrm{C}$, respectively. The vineyard was a 0.4 -ha drip-irrigated block, cv. Barbera, planted in 1989, with $3 \mathrm{~m}$ between rows and $2.1 \mathrm{~m}$ between vines within the row. Soil type at the site was a Hanford series fine sandy loam.

This study's focus on nodding needlegrass and its effect on water relations was part of a larger experiment on vineyard cover crops (Costello, 2010). Cover crop treatments were established in Nov. 1996, and nodding needlegrass was planted at a rate of 13.2 $\mathrm{kg} \cdot \mathrm{ha}^{-1}$ equivalent. Plot size was five rows by six vines $\left(189 \mathrm{~m}^{2}\right)$, and the cover crop treatments and a clean cultivated control were replicated three times in a randomized complete block design. The between-row width planted to the cover crops was $2 \mathrm{~m}$, leaving a $1-\mathrm{m}$ band in-row treated with herbicide. Neutron probe tubes made of polyvinyl chloride were placed in each nodding needlegrass and control plots, one within the row and one between rows (i.e., a total of three in-row and three between-row neutron probe tubes for each treatment). The in-row probes were placed midway between drip emitters.

The vineyard was irrigated daily at $80 \%$ of estimated crop evapotranspiration $\left(\mathrm{ET}_{\mathrm{c}}\right)$ from 1 May to 1 Nov. of each year, which optimizes yield according to Williams (2000). Daily reference evapotranspiration figures were taken from the California Irrigation Management Information System weather station located on-site and monthly crop coefficient values from Williams et al. (2003). Rainfall outside of the study season (1 Oct. to 31 May) was $432 \mathrm{~mm}$ for $1997-$ 1998 and $202 \mathrm{~mm}$ for 1998-1999. Estimated total irrigation water applied was $503 \mathrm{~mm}$ (1998) and $538 \mathrm{~mm}$ (1999). The only other water inputs during the study periods were $\approx 15 \mathrm{~mm}$ of rain (between 6 and 12 June 1998), and an accidental flood irrigation, which provided the entire block, with $\approx 12$ mm of water (6 Aug. 1999).

Vine water status was estimated biweekly from these same treatments using a pressure bomb (PMS Instruments, Corvallis, OR), taking five readings per plot between the hours of 1100 and 1400 HR. Leaves selected for measurement were mature and in full sun. For each leaf, the petiole was cut with a razor blade, the entire leaf was placed into a plastic bag, and placed into the chamber within $30 \mathrm{~s}$. Williams and Araujo (2002) found that bagging after cutting the petiole resulted in lower readings than if the leaf were bagged before cutting $(\approx 12 \%$ lower at an irrigation regime of $100 \% \mathrm{ET}_{\mathrm{c}}$ ).

Soil moisture status was estimated using a neutron probe (Model 503DR; Campbell 

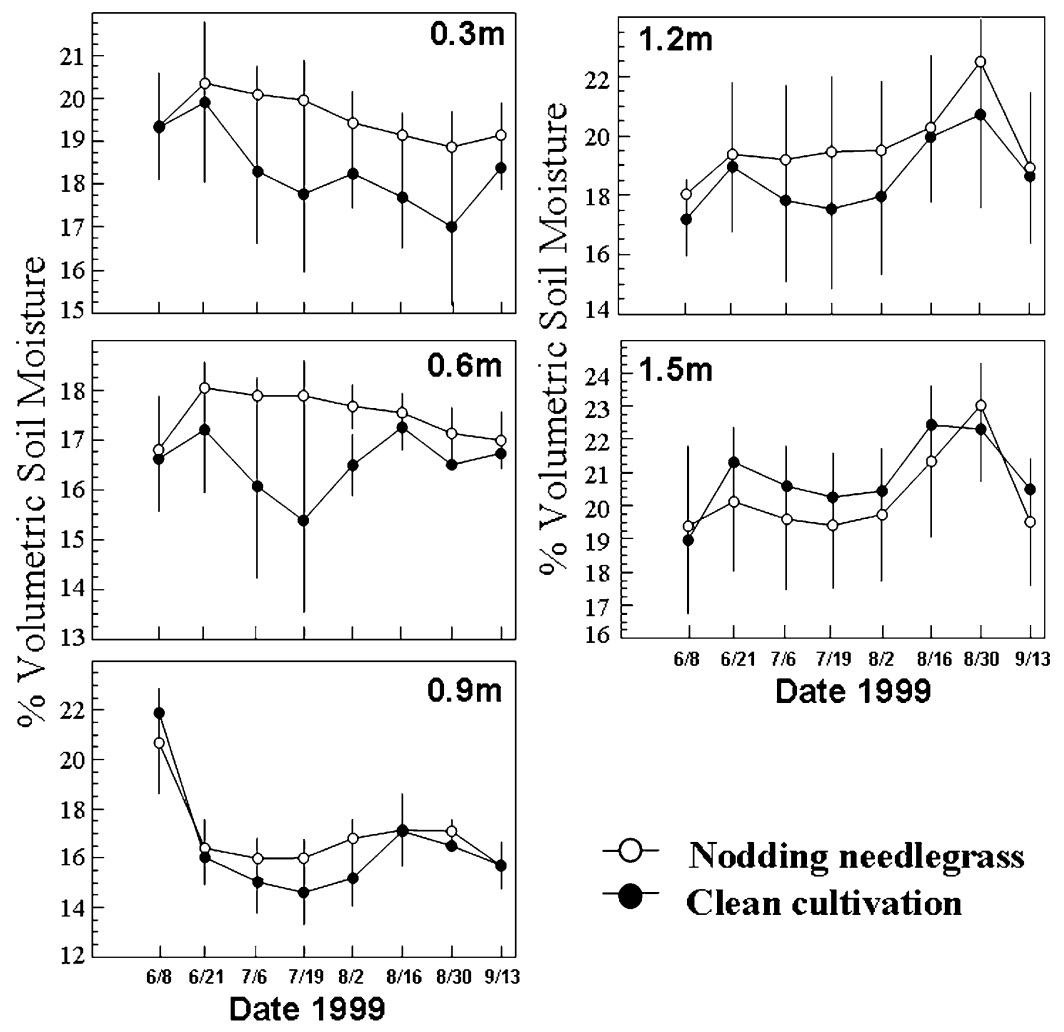

Fig. 3. Mean between-row soil moisture, 1998 season. Percent volumetric soil moisture content \pm SE estimated from neutron probe readings taken weekly from June to September, nodding needlegrass versus clean cultivation treatments.
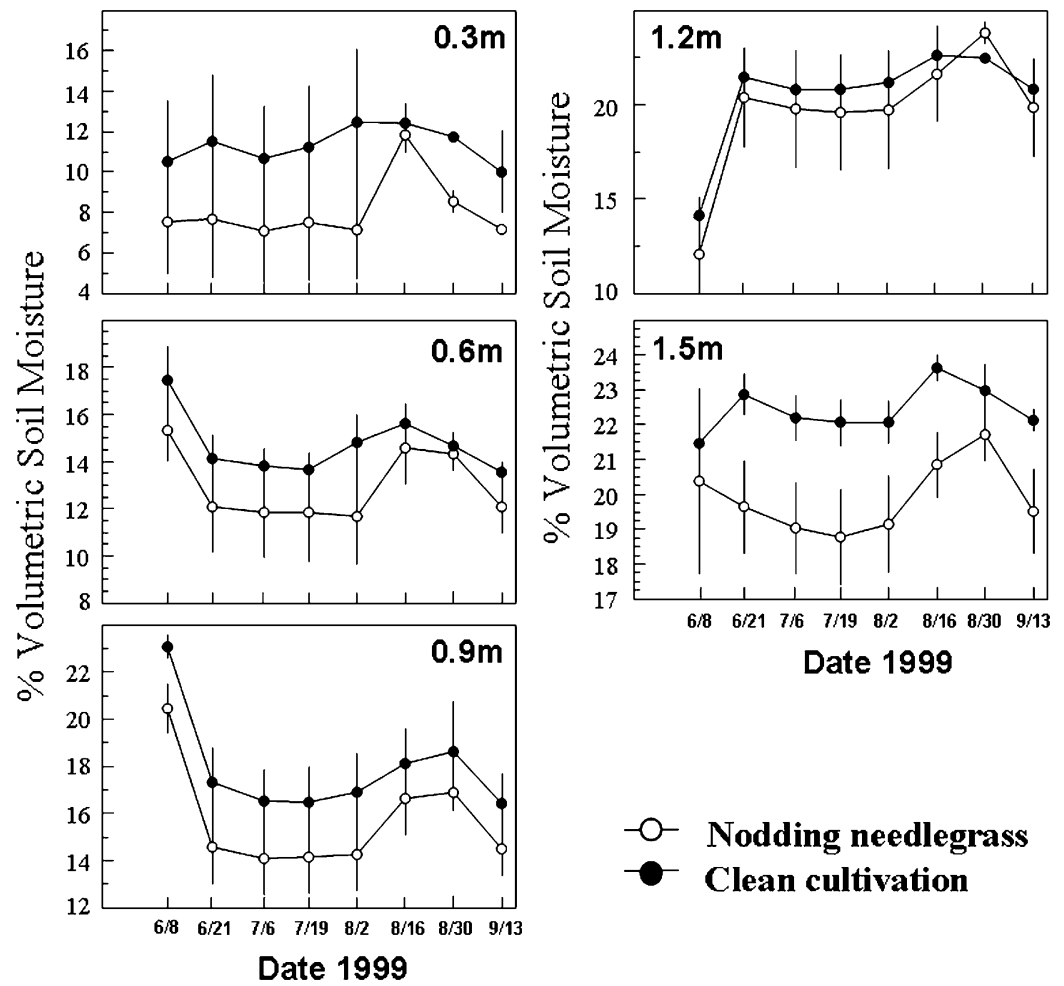

\section{$-{ }_{-}^{-}$Nodding needlegrass Clean cultivation}

Fig. 4. Mean between-row soil moisture, 1999 season. Percent volumetric soil moisture content $\pm \mathrm{SE}$ estimated from neutron probe readings taken weekly from June to September, nodding needlegrass versus clean cultivation treatments.

Pacific Nuclear, Martinez, CA). Readings were taken every 2 weeks from May through September at depths of $0.3 \mathrm{~m}, 0.6 \mathrm{~m}, 0.9 \mathrm{~m}$, $1.2 \mathrm{~m}$, and $1.5 \mathrm{~m}$ from the neutron probe tubes within the vine row and between rows in each plot. Volumetric soil moisture content was determined from soil core samples taken at the beginning of the study from each of the probe locations. In all, 18 core samples were taken, and neutron probe readings were taken at the same time. The neutron probe was read as counts during $30 \mathrm{~s}$. The soil cores were weighed, oven-dried at $100{ }^{\circ} \mathrm{C}$ for $48 \mathrm{~h}$, and then weighed again. These values were regressed against actual neutron probe readings at each location to get an estimate of percent volumetric soil moisture content. The regression equation was $\mathrm{y}=-3.0171+$ $0.0016 \mathrm{x}\left(r^{2}=0.73, P<0.01\right)$, in which $\mathrm{y}=$ volumetric soil moisture content $(\% \mathrm{w} / \mathrm{v})$ and $\mathrm{x}=$ neutron probe reading.

Cover crop management consisted of one mowing to a height of $15 \mathrm{~cm}$ in the middle of June of each year, and between-row weed control in the clean cultivated treatment was undertaken every 2 weeks by use of a tractordrawn rototiller. For the entire study site, inrow weed control was accomplished by a band-spray application of glyphosate to the $1 \mathrm{~m}$ in-row area $(2.6 \mathrm{~kg}$ glyphosate acid equivalent/ha) in March and May.

Soil moisture and leaf water potential were analyzed by repeated-measures analysis of variance (ANOVA) using year or date as the repeated-measures ("within-subjects") variable using orthogonal contrasts for mean separation (PROC GLM; SAS Institute, 2003). Differences between means were considered significant with $P<0.05$. Regression analysis was performed by regressing soil moisture readings (pooling dates and years) against soil depth for in-row and between-row locations (PROC REG; SAS Institute, 2003). The between-row data were best fitted to a secondorder polynomial, whereas the in-row data were best fitted to a third-order polynomial. Linear regression analysis was performed on the between-row data only to estimate the rate of change in soil moisture over the season (PROC REG; SAS Institute, 2003), and $t$ tests were calculated to compare the slopes between treatments at each soil depth.

\section{Results}

Soil moisture. Figures 1 through 4 show in-row and between-row soil moisture per $0.3 \mathrm{~m}$ of soil depth by date for the 1998 and 1999 seasons. There was no year $\times$ treatment interaction for between-row nor in-row soil moisture data (Table 1), which justified the repeated-measures analyses. However, there was year $\times$ treatment $\times$ date interactions for the between-row and in-row data (Table 1), so the analyses using date as the repeated-measures variable were conducted for each year.

Comparison between treatments across dates using year as the repeated-measures variable. Pooling all dates, the in-row data showed a significant treatment $\times$ depth interaction (Table 1) with a pattern of higher soil moisture in the nodding needlegrass treatment compared with clean cultivation at the shallow depths but the opposite occurring at the lowest depth (Figs. 1 and 2; Table 2 ). In-row soil moisture was higher in the nodding needlegrass treatment compared with clean cultivation by $2.14 \%$ points at $0.3 \mathrm{~m}$ and by $1.56 \%$ points at $0.6 \mathrm{~m}$. In 
contrast, the clean cultivation treatment was higher than nodding needlegrass by $1.21 \%$ points at $1.5 \mathrm{~m}$ (Table 2). There was no significant difference between treatments at $0.9 \mathrm{~m}$ or $1.2 \mathrm{~m}$ (Table 2 ).

Again pooling study dates, the betweenrow data showed no treatment $x$ depth interaction (Table 1) with a consistent pattern of higher soil moisture in the clean cultivated versus cover crop treatment at all soil depths (Figs. 3 and 4; Table 3). Overall, betweenrow soil moisture was significantly higher under clean cultivation compared with nodding needlegrass by $2.07 \%$ points at $0.3 \mathrm{~m}$, $1.51 \%$ points at $0.6 \mathrm{~m}, 2.10 \%$ points at $0.9 \mathrm{~m}$, $1.51 \%$ points at $1.2 \mathrm{~m}$, and $3.16 \%$ points at $1.5 \mathrm{~m}$ (Table 3). Between-row soil moisture began to decline in both treatments in midJuly, most dramatically at the shallower depths, probably as a result of the increase in ambient air temperature and subsequent increase in evaporation at that time.

Pooling soil depths and dates, in-row percent moisture was $0.9 \%$ points higher in the nodding needlegrass treatment (Table 2), and between-row percent moisture was $1.9 \%$ points higher in the clean cultivation treatment (Table 3).

Comparison across depths by location and treatment using year as the repeatedmeasures variable. For the in-row location, the repeated-measures ANOVA for soil moisture across depths was significant for nodding needlegrass as well as clean cultivation (Table 4). For nodding needlegrass, orthogonal contrasts indicated no significant differences between $0.3 \mathrm{~m}$ and $0.6 \mathrm{~m}, 0.6 \mathrm{~m}$ and $0.9 \mathrm{~m}$, nor $1.2 \mathrm{~m}$ and $1.5 \mathrm{~m}$ (Table 4). However, there was a significant increase between $0.9 \mathrm{~m}$ and $1.2 \mathrm{~m}$ by $2.92 \%$ points (Table 4). For clean cultivation, orthogonal contrasts showed no significant differences between $0.3 \mathrm{~m}$ and $0.6 \mathrm{~m}$ nor between $0.6 \mathrm{~m}$ and $0.9 \mathrm{~m}$ (Table 4). However, there were significant increases between $0.9 \mathrm{~m}$ and $1.2 \mathrm{~m}$ (by $2.69 \%$ points) and between $1.2 \mathrm{~m}$ and $1.5 \mathrm{~m}$ (by $1.78 \%$ points) (Table 4 ).

For the between-row location, repeatedmeasures ANOVA for soil moisture across depths was significant for nodding needlegrass (Table 5) as well as clean cultivation (Table 5). Both treatments showed a depth gradient with soil moisture significantly different between each successive depth from $0.3 \mathrm{~m}$ to $1.2 \mathrm{~m}$ as shown by orthogonal contrasts, but no difference between $1.2 \mathrm{~m}$ and $1.5 \mathrm{~m}$ (Table 5). In the nodding needlegrass treatment, the differences in percentage points were $5.3,2.6$, and 4.4 between $0.3 \mathrm{~m}$ and $0.6 \mathrm{~m}, 0.6 \mathrm{~m}$ and $0.9 \mathrm{~m}$, and $0.9 \mathrm{~m}$ to 1.2 $\mathrm{m}$, respectively (Table 5 ). In the clean cultivated treatment, the percentage point differences were $4.7,3.2$, and 3.7 between $0.3 \mathrm{~m}$ and $0.6 \mathrm{~m}, 0.6 \mathrm{~m}$ and $0.9 \mathrm{~m}$, and $0.9 \mathrm{~m}$ and $1.2 \mathrm{~m}$, respectively (Table 5).

Regressions of soil moisture by soil depth. The disproportionate distribution of in-row water can be seen in the regressions of soil moisture against soil depth, which show a nonlinear relationship, which best fit to a third-order polynomial (Fig. 5). For nod-

Table 1. Analysis of variance interaction terms for soil moisture data. ${ }^{\mathrm{z}}$

\begin{tabular}{lllrrr}
\hline Yr & Location & Interaction term & F & df & $P$ \\
- & In-row & Year*treatment & 0.58 & 1,430 & 0.45 \\
- & Between-row & Year*treatment & 0.02 & 1,430 & 0.89 \\
- & In-row & Year*treatment*date & 2.27 & 21,430 & $<0.01$ \\
- & Between-row & Year*treatment*date & 6.09 & 21,430 & $<0.01$ \\
Pooled & In-row & Treatment*depth & 3.59 & 4,214 & $<0.01$ \\
Pooled & Between-row & Treatment*depth & 1.61 & 4,214 & 0.17 \\
1998 & Between-row & Treatment*date & 0.88 & 7,182 & 0.52 \\
1999 & Between-row & Treatment*date & 2.21 & 7,182 & 0.03 \\
\hline
\end{tabular}

zTreatments are nodding needlegrass and clean cultivation.

Table 2. In-row mean percent soil moisture $(\% \mathrm{w} / \mathrm{v}) \pm$ SE for nodding needlegrass and clean cultivation treatments, 1998 and 1999 seasons combined. $^{z}$

\begin{tabular}{lcccc}
\hline Depth $(\mathrm{m})$ & Nodding needlegrass & Clean cultivation & $\mathrm{F}$ & $P$ \\
\hline 0.3 & $17.20 \pm 0.69$ & $15.04 \pm 0.87$ & 4.74 & 0.03 \\
0.6 & $16.37 \pm 0.37$ & $14.42 \pm 0.54$ & 6.50 & 0.01 \\
0.9 & $15.23 \pm 0.43$ & $14.64 \pm 0.48$ & 2.61 & 0.11 \\
1.2 & $18.15 \pm 0.65$ & $17.33 \pm 0.59$ & 2.65 & 0.11 \\
1.5 & $17.99 \pm 0.68$ & $19.11 \pm 0.52$ & 4.58 & 0.04 \\
Combined & $17.56 \pm 0.25$ & $16.63 \pm 0.28$ & 6.70 & 0.01 \\
\hline
\end{tabular}

${ }^{\mathrm{z}}$ Analysis of variance statistics using year as the repeated-measures variable are for comparison of treatment means at each depth $(\mathrm{df}=1,44)$ or combined depths $(\mathrm{df}=1,236)$.

Table 3. Between-row average percent soil moisture ( $\% \mathrm{w} / \mathrm{v}) \pm \mathrm{sE}$ for nodding needlegrass and clean cultivated treatments, 1998 and 1999 seasons combined. ${ }^{\mathrm{z}}$

\begin{tabular}{lcrrr}
\hline Depth $(\mathrm{m})$ & Nodding needlegrass & Clean cultivation & \multicolumn{1}{c}{ F } & $P$ \\
\hline 0.3 & $5.41 \pm 0.48$ & $7.48 \pm 0.59$ & 8.37 & $<0.01$ \\
0.6 & $10.73 \pm 0.45$ & $12.24 \pm 0.36$ & 14.17 & $<0.01$ \\
0.9 & $13.28 \pm 0.47$ & $15.38 \pm 0.60$ & 18.07 & $<0.01$ \\
1.2 & $17.65 \pm 0.82$ & $19.16 \pm 0.50$ & 4.68 & 0.04 \\
1.5 & $17.05 \pm 0.64$ & $20.21 \pm 0.55$ & 16.40 & $<0.01$ \\
Combined & $13.38 \pm 0.39$ & $15.28 \pm 0.38$ & 7.62 & $<0.01$ \\
\hline
\end{tabular}

${ }^{\mathrm{z}}$ Analysis of variance statistics using year as the repeated-measures variable are for comparison of treatment means at each depth $(\mathrm{df}=1,44)$ or combined depths $(\mathrm{df}=1,236)$.

Table 4. In-row repeated-measures analysis of variance (ANOVA) statistics and orthogonal contrasts for comparison of means across depths for nodding needlegrass and clean cultivated treatments.

\begin{tabular}{lcrrr}
\hline & & \multicolumn{1}{c}{ F } & \multicolumn{1}{c}{$P$} \\
\hline Nodding needlegrass & Repeated-measures ANOVA & 3.92 & 4,113 & $<0.01$ \\
& 0.3 m versus $0.6 \mathrm{~m}$ & 0.76 & 1,113 & 0.38 \\
& 0.6 m versus $0.9 \mathrm{~m}$ & 1.16 & 1,113 & 0.28 \\
& 0.9 m versus $1.2 \mathrm{~m}$ & 11.92 & 1,113 & $<0.01$ \\
Clean cultivated & 1.2 m versus $1.5 \mathrm{~m}$ & 0.23 & 1,113 & 0.63 \\
& Repeated-measures ANOVA & 12.67 & 4,113 & $<0.01$ \\
& 0.3 m versus $0.6 \mathrm{~m}$ & 1.11 & 1,113 & 0.30 \\
& 0.6 m versus $0.9 \mathrm{~m}$ & 0.10 & 1,113 & 0.76 \\
& 0.9 m versus $1.2 \mathrm{~m}$ & 5.94 & 1,113 & 0.02 \\
& 1.2 m versus $1.5 \mathrm{~m}$ & 5.96 & 1,113 & 0.02 \\
\hline
\end{tabular}

Table 5. Between-row repeated-measures analysis of variance (ANOVA) statistics and orthogonal contrasts for comparison of means across depths within the nodding needlegrass and clean cultivated treatments.

\begin{tabular}{lcrrr}
\hline & & F & df & $P$ \\
\hline Nodding needlegrass & Repeated-measures ANOVA & 138.4 & 4,113 & $<0.01$ \\
& 0.3 m versus $0.6 \mathrm{~m}$ & 155.47 & 1,113 & $<0.01$ \\
& 0.6 m versus $0.9 \mathrm{~m}$ & 11.09 & 1,113 & $<0.01$ \\
& 0.9 m versus $1.2 \mathrm{~m}$ & 18.89 & 1,113 & $<0.01$ \\
Clean cultivated & 1.2 m versus $1.5 \mathrm{~m}$ & 0.00 & 1,113 & 0.99 \\
& Repeated-measures ANOVA & 150.3 & 4,113 & $<0.01$ \\
& 0.3 m versus $0.6 \mathrm{~m}$ & 132.66 & 1,113 & $<0.01$ \\
& 0.6 m versus $0.9 \mathrm{~m}$ & 18.99 & 1,113 & $<0.01$ \\
& 0.9 m versus $1.2 \mathrm{~m}$ & 19.24 & 1,113 & $<0.01$ \\
& 1.2 m versus $1.5 \mathrm{~m}$ & 1.47 & 1,113 & 0.23 \\
\hline
\end{tabular}

ding needlegrass, soil moisture was highest at the shallowest and lowest depths and lowest between 0.6 and $0.9 \mathrm{~m}$ (Fig. 5). There was a similar effect for clean cultivation, although in 1998, soil moisture at the $0.3-\mathrm{m}$ depth was quite low and did not match the pattern. The regressions also clearly show the interaction between treatment and soil depth at the inrow location; at depths shallower than $1.2 \mathrm{~m}$, there was higher moisture with nodding 


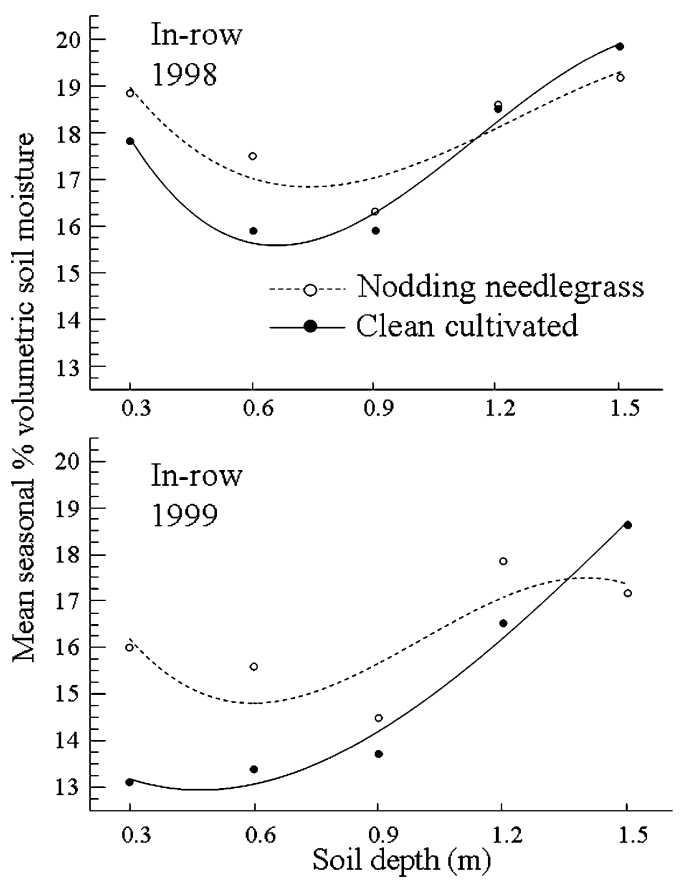

Fig. 5. Third-order polynomial regression of mean seasonal in-row soil moisture (pooled by date for each year) against soil depth for nodding needlegrass and clean cultivation. 1998 nodding needlegrass $\mathrm{y}=$ $21.5-26.0 \mathrm{x}+31.1 \mathrm{x}^{2}-10.4 \mathrm{x}^{3}, r^{2}=0.618 ; 1998$ clean cultivation $\mathrm{y}=14.9-8.9 \mathrm{x}+11.1 \mathrm{x}^{2}-2.3 \mathrm{x}^{3}, r^{2}=$ $0.980 ; 1999$ nodding needlegrass $\mathrm{y}=23.8-21.9 \mathrm{x}+21.2 \mathrm{x}^{2}-5.7 \mathrm{x}^{3}, r^{2}=0.812 ; 1999$ clean cultivation $\mathrm{y}=24.6+-31.7 \mathrm{x}+33.8 \mathrm{x}^{2}-9.8 \mathrm{x}^{3}, r^{2}=0.974$.

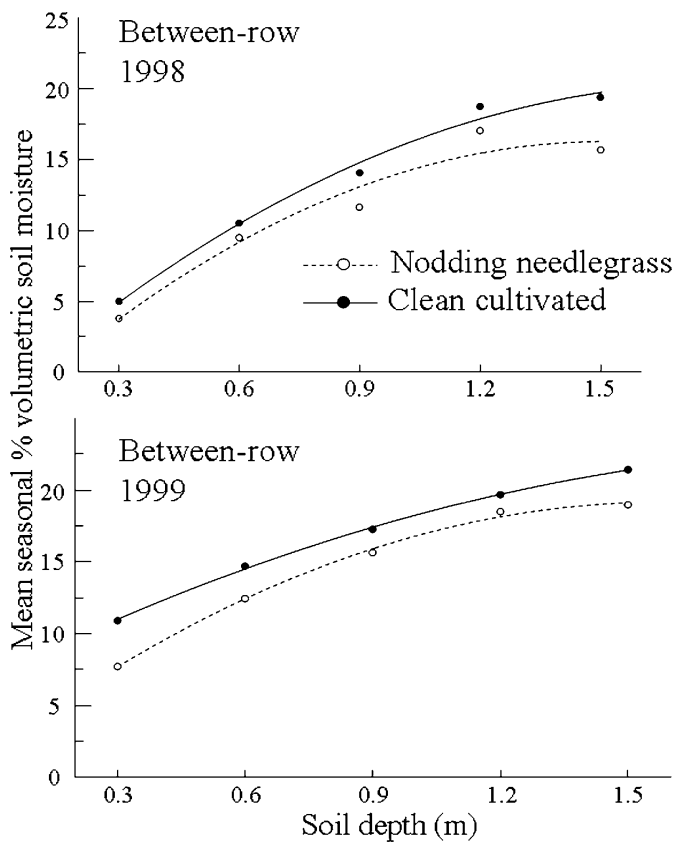

Fig. 6. Second-order polynomial regression of mean seasonal between-row soil moisture (pooled by date for each year) against soil depth for nodding needlegrass and clean cultivation. 1998 nodding needlegrass $\mathrm{y}=-3.3+25.9 \mathrm{x}-8.6 \mathrm{x}^{2}, r^{2}=0.954 ; 1998$ clean cultivation $\mathrm{y}=-1.8+24.6 \mathrm{x}-6.8 \mathrm{x}^{2}, r^{2}=$ $0.989,1999$ nodding needlegrass $\mathrm{y}=1.7+22.2 \mathrm{x}-6.9 \mathrm{x}^{2}, r^{2}=0.997 ; 1999$ clean cultivation $\mathrm{y}=6.8+$ $14.7 \mathrm{x}-3.4 \mathrm{x}^{2}, r^{2}=0.999$.

needlegrass, but at $1.5 \mathrm{~m}$, the highest moisture was with clean cultivation (Fig. 5).

Regression analysis for the between-row data showed a similar pattern for each year: a positive, nonlinear relationship between soil moisture and increasing depth for each treatment, which best fit to a second-order polynomial (Fig. 6). For each treatment, soil moisture increased from the $0.3-\mathrm{m}$ to $1.2-\mathrm{m}$ depths (Fig. 6) and had an asymptote at $1.5 \mathrm{~m}$.

Linear regression analysis showed no significant difference $(P>0.05)$ between treatments in the rate of between-row soil moisture change over the course of the season in either study year.

Comparison of between-row soil moisture across depths using date as the repeatedmeasures variable. Pooling soil depths, the between-row soil moisture treatment $\times$ date interaction was not significant in 1998 (Table 1), indicating that soil moisture loss was consistent between treatments throughout the season (Fig. 3). The between-row soil moisture treatment $\times$ date interaction was significant in 1999 (Table 1), but this was a result of the flood irrigation on 6 Aug., because the relationship between the cover crop and clean cultivated treatments did not change until the reading on 16 Aug. (Fig. 4).

Vine water status. The pattern of leaf water potentials over the season was very similar between years with water stress in both nodding needlegrass and clean cultivation increasing rapidly around the end of July to the beginning of August (Fig. 7). Repeated-measures ANOVA did not reveal any significant differences between nodding needlegrass and clean cultivated treatments $(\mathrm{F}=0.27, \mathrm{df}=1,188, P=0.60$; Fig. 7$)$.

\section{Discussion}

The lack of difference in vine leaf water potential indicates that overall soil moisture availability was similar between treatments. Likewise, Celette et al. (2005) found no significant differences in vine water status with a tall fescue cover crop, and Ingels et al. (2005) found little to no difference in vine leaf water potential between clean cultivation and a California native grass blend.

Although overall vineyard soil moisture (combining in-row and between-row data) was slightly lower (by $1.2 \%$ points) with nodding needlegrass as a cover crop, this was largely because of higher between-row soil moisture under clean cultivation, which was not offset by the slightly higher in-row moisture with the nodding needlegrass cover crop. If the vine roots were located primarily in the in-row zone as has been shown for drip-irrigated vineyards (Stevens and Douglas, 1994), the extra water use by the nodding needlegrass cover crop in the between-row zone, occurring primarily during the off-season, should have had little effect on vine growth or yield. Indeed, this was the case, because yield and pruning weight with nodding needlegrass as a cover crop was equivalent with clean cultivation (Costello, 2010).

That there was higher overall in-row soil moisture in the nodding needlegrass treatment suggests two possibilities: compared with clean cultivation, in the nodding needlegrass treatment vine water use was less or water infiltration was greater. With respect to the possibility of lower vine water use, in-row soil moisture with nodding needlegrass was significantly higher than clean cultivation only at the two shallowest soil depths $(0.3$ $\mathrm{m}$ and $0.6 \mathrm{~m}$ ), suggesting that competition with the cover crop may have decreased vine 


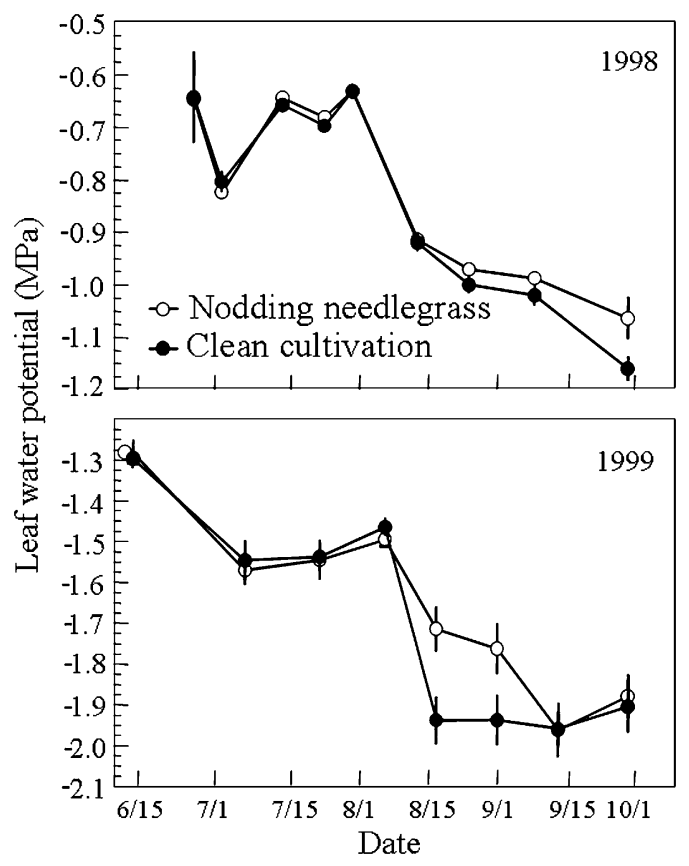

Fig. 7. Mean leaf water potential $(\mathrm{MPa}) \pm \mathrm{SE}$, nodding needlegrass versus clean cultivation treatments, 1998 and 1999 seasons.

root activity and led to lower water uptake. However, this does not seem likely if nodding needlegrass has a high degree of summer dormancy, because the only periods of overlapping root activity, and therefore, competition, would be in spring and fall. In the current study, neither cover crop nor vine rooting structure was analyzed, and there are no published studies on the rooting pattern of nodding needlegrass nor any closely related species. Celette et al. (2008), working in an unirrigated vineyard, found grapevine root density was significantly affected by the perennial cover crop blend of tall fescue and perennial ryegrass (Lolium perenne L.), but only in the shallow soil depths. However, the results were not consistent, because grapevine root density was higher with bare soil one year and higher under cover crop management in the next year. Morlat and Jacquet (2003) found that a tall fescue cover crop in an unirrigated vineyard had an effect on shallow grapevine root density, increasing at the edge of the cover crop but decreasing in the center of the cover crop. Monteiro and Lopes (2007) compared resident vegetation, a perennial cover crop, and bare soil in an unirrigated vineyard and found that vine water use at different depths varied by season; during the postveraison period, the cover crop and resident vegetation treatments used proportionately more water from the shallow depths. This suggests that there was more competition for water in these treatments. In the current study, if the higher in-row soil moisture in the nodding needlegrass treatment means that these vines used less in-row water, this should have been reflected in a smaller vine canopy, i.e., having lower vigor, than under clean cultivation. However, the vines in the nodding needlegrass and clean cultivation treatments had equivalent pruning weights, which is an index of vigor and canopy size, and vine trunk diameter was greater in the nodding needlegrass treatment compared with clean cultivation (Costello, 2010). There is therefore little evidence that lower vine water use explains the higher inrow soil moisture content in the nodding needlegrass treatment.

The other possible explanation for higher in-row soil moisture with nodding needlegrass is improved water infiltration. This was the explanation of Celette et al. (2005) to the higher overall vineyard soil moisture found with a cover crop of $F$. arundinacea. They suggested this was the result of better water infiltration with winter rains. However, in the current study, the mechanism would be somewhat different because the study vineyard did not depend on winter rain, but rather on drip irrigation. Still, it is possible that the presence of nodding needlegrass could have affected in-season irrigation water infiltration through lateral root channels. Although the rooting structure of nodding needlegrass has not been looked at, average lateral root distribution for perennial grasses (one-sided) is $\approx 0.5 \mathrm{~m}$ (Schenk and Jackson, 2002). Several eastern U.S. perennial native grasses show a negative gradient from shallow to deep in the lateral distribution of roots (Brown et al., 2010). It is possible that the lateral root distribution of nodding needlegrass is more extensive at the shallower depths (less than $0.6 \mathrm{~m}$ ) declines between $0.6 \mathrm{~m}$ and $1.2 \mathrm{~m}$ and is insignificant at greater than $1.2 \mathrm{~m}$. This is reflected in the pattern of in-row soil moisture between treatments by depth (Table 2; Figs. 1 and 2) and can also be seen in the regression analysis (Fig. 5). At $1.5 \mathrm{~m}$, there is significantly higher soil moisture under clean cultivation, reversing the pattern at less than $0.6 \mathrm{~m}$.
The data suggest that between-row water use by the grapevines was not significant. This is indicated by the lack of interaction between treatment and depth in between-row soil moisture and because the pattern of soil moisture by depth for the between-row zone did not at all resemble the pattern of in-row soil moisture. If the vines had used betweenrow moisture, there would have been a disproportionate draw at the same depth of peak in-row use (i.e., $0.6 \mathrm{~m}$ to $0.9 \mathrm{~m}$ ). Indeed, this was not the case, as can be seen in Figures 3 and 4 , and by comparing the regressions seen in Figures 5 and 6 . In addition, because under clean cultivation, the soil was rototilled at a depth of $\approx 15 \mathrm{~cm}$, this reduced vine root activity within the $0.3-\mathrm{m}$ depth compared with nodding needlegrass, which was not disturbed. If the vines had used water at this depth, then water use in the nodding needlegrass treatment would have been a combination of nodding needlegrass and vine use, and the results would have shown a disproportionately lower soil moisture content at $0.3 \mathrm{~m}$ versus the other depths in the nodding needlegrass treatment compared with clean cultivation. This was also not the case. Therefore, it appears that vine water use was limited to the in-row soil region.

Although the degree or mechanism of nodding needlegrass summer dormancy cannot be determined from this study, the data indicate that summer water use by nodding needlegrass was minimal. This can be seen in the lack of difference in the rate of change of between-row soil moisture between June and September (Figs. 3 and 4). The corollary, therefore, is that although overall soil moisture was lower with the cover crop, most if not all of this deficit was created between October and May when the grass is active. This suggests that nodding needlegrass is drought-tolerant rather than drought-avoidant (Levitt, 1980). If it were drought-avoidant, one might expect it to have used the nearby and available in-row water, which was not the case given that in-row soil moisture was higher in the nodding needlegrass treatment.

For the 3 years of this study, nodding needlegrass appeared to be suitable agronomically; it established well, tolerated tractor traffic and mowing, tolerated summer heat and drought, and had a minimal effect on overall soil moisture. Based on these results, nodding needlegrass appears to be suitable as a permanent cover crop in California dripirrigated vineyards where competition for summer water is a concern.

\section{Literature Cited}

Amme, D. 2003. Nassella notes. Grasslands 13.

Barkworth, M.E. and M.A. Torres. 2001. Distribution and diagnostic characters of Nassella (Poaceae:Stipeae). Taxon 50:439-468.

Baumgartner, K., K.L. Steenwerth, and L. Veilleux. 2008. Cover crop systems affect weed communities in a California vineyard. Weed Sci. 56:596-605.

Beetle, A.A. 1947. Distribution of the native grasses of California. Hilgardia 17:309-357.

Brown, R.N., C. Percivalle, S. Narkiewicz, and S. DeCuollo. 2010. Relative rooting depths of 
native grasses and amenity grasses with potential for use on roadsides. HortScience 45:393-400.

Celette, F., R. Gaudin, and C. Gary. 2008. Spatial and temporal changes to the water regime of a Mediterranean vineyard due to the adoption of cover cropping. Eur. J. Agron. 29:153-162.

Celette, F., J. Wery, E. Chantelot, J. Celette, and C. Gary. 2005. Belowground interactions in a vine (Vitis vinifera L.)-tall Fescue (Festuca arundinacea Shreb.) intercropping system: Water relations and growth. Plant Soil 276:205-217.

Clary, J.J. 2006. Distribution and ecophysiological adaptations of annual and perennial grasses in Mediterranean climate zones of California and the Iberian Peninsula. $\mathrm{PhD}$ diss., Univ. of Calif., Davis. UMI 3230617.

Costello, M.J. 2010. Growth and yield of cultivated grape with native perennial grasses nodding needlegrass or California barley as cover crops. HortScience 45:154-156.

Goulet, E., S. Dousset, R. Chaussod, F. Bartoli, A.F. Doledec, and F. Andreux. 2004. Waterstable aggregates and organic matter pools in a calcareous vineyard soil under four soilsurface management systems. Soil Use Manage. 20:318-324.

Gulick, S.H., D.W. Grimes, D.S. Munk, and D.A. Goldhammer. 1994. Cover-crop-enhanced water infiltration of a slowly permeable fine sandy loam. Soil Sci. Soc. Amer. J. 58:1539-1546.

Ingels, C.A., R.L. Bugg, and F.L. Thomas. 1998. Implementation of cover cropping in vineyards: Grower practices, p. 8-25. In: Ingels, C., R.L. Bugg, G.T. McGourty and L.P. Christensen (eds.). Cover cropping in vineyards: A growers handbook. University of California Division of Agriculture and Natural Resources, Oakland, CA.

Ingels, C.A., K.M. Scow, D.A. Whisson, and R.E. Drenovsky. 2005. Effects of cover crops on grapevines, yield, juice composition, soil microbial ecology, and gopher activity. Amer. J. Enol. Viticult. 56:19-29.

King, A.P. and A.M. Berry. 2005. Vineyard $\delta^{15}$, nitrogen and water status in perennial clover and bunch grass cover crop systems of California's central valley. Agr. Ecosyst. Environ. 109:262-272.

Klik, A., J. Rosner, and W. Loiskandl. 1998. Effects of temporary and permanent soil cover on grape yield and soil chemical and physical properties. J. Soil Water Conserv. 53:249253.

Levitt, J. 1980. Responses of plants to environmental stresses. Academic Press, London, UK.

McGourty, G.T. and L.P. Christensen. 1998. Cover cropping systems and their management, p. 4357. In: Ingels, C., R.L. Bugg, G.T. McGourty and L.P. Christensen (eds.). Cover cropping in vineyards: A growers handbook. University of California Division of Agriculture and Natural Resources, Oakland, CA.

Monteiro, A. and C.M. Lopes. 2007. Influence of cover crop on water use and performance of vineyard in Mediterranean Portugal. Agr. Ecosyst. Environ. 121:336-342.

Morlat, R. and A. Jacquet. 2003. Grapevine root system and soil characteristics in a vineyard maintained long-term with or without interrow sward. Amer. J. Enol. Viticult. 54:1-7.
Prichard, T.L., W.M. Sills, W.K. Asai, L.C. Hendricks, and C.L. Elmore. 1989. Orchard water use and soil characteristics. Calif. Agr. 43:2325.

SAS Institute. 2003. SAS/STAT user's guide, release 9.1. SAS Institute, Cary, NC.

Schenk, H.J. and R.B. Jackson. 2002. Rooting depths, lateral root spreads and below-ground/ above-ground allometries of plants in waterlimited ecosystems. J. Ecol. 90:480-494.

Stevens, R.M. and T. Douglas. 1994. Distribution of grapevine roots and salt under drip and fullground cover microjet irrigation systems. Irrig. Sci. 15:147-152.

Williams, L.E. 2000. Grapevine water relations, p. 121-126. In: Christensen, L.P. (ed.). Raisin production manual. DANR Publications, University of California, Oakland, CA.

Williams, L.E. and F.J. Araujo. 2002. Correlations among predawn leaf, midday leaf, and midday stem water potential and their correlations with other measures of soil and plant water status in Vitis vinifera. J. Amer. Soc. Hort. Sci. 127:448454.

Williams, L.E., C.J. Phene, D.W. Grimes, and T.J. Trout. 2003. Water use of mature Thompson Seedless grapevines in California. Irrig. Sci. 22:11-18.

Winkler, A.J., J.A. Cook, W.M. Kliewer, and L.A. Lider. 1974. General viticulture. University of California Press, Berkeley, CA.

Wolpert, J.A., P.A. Phillips, R.K. Striegler, M.V. McKenry, and J.H. Foott. 1993. Berber orchardgrass tested as cover crop in commercial vineyard. Calif. Agr. 47:23-25. 